\title{
Periodontitis as a risk factor for head and neck cancer
}

\author{
Letícia Miquelitto Gasparoni ${ }^{1}$, Fábio Abreu Alves ${ }^{1,2}$, Marinella Holzhausen ${ }^{1}$, Cláudio Mendes Pannuti ${ }^{1}$, \\ Marianna Sampaio Serpa ${ }^{2}$
}

${ }^{1}$ Department of Stomatology, School of Dentistry, University of São Paulo, Brazil

${ }^{2}$ Department of Stomatology, A.C.Camargo Cancer Center, São Paulo, Brazil

Correspondence:

Department of Stomatology

A.C.Camargo Cancer Center

São Paulo, Brazil

marianna.serpa@accamargo.org.br

Received: 25/08/2020

Accepted: 08/12/2020

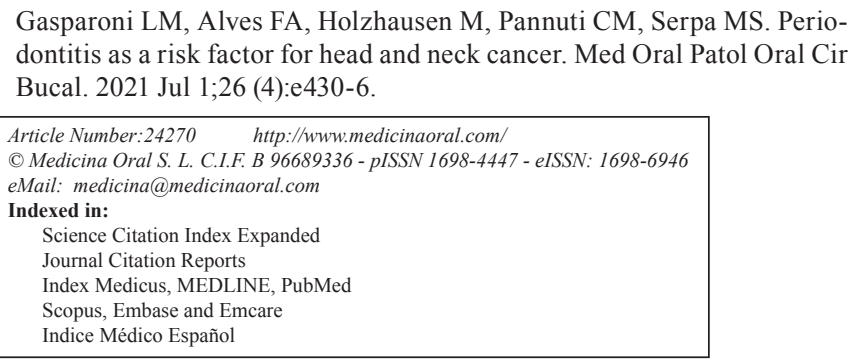

\begin{abstract}
Background: Periodontitis may be associated with the development of head and neck cancer (HNC). A literature review was conducted to understand the possible association between them.

Material and Methods: Articles published in the PubMed database from January 1999 and May 2020 were retrieved. Limitations of the studies and biological mechanisms were discussed.

Results: A total of 4,232 articles were found. Of these, 13 were analyzed according to inclusion criteria. Most papers found some association between periodontitis and $\mathrm{HNC}$, although differences in periodontal evaluation, sample size, study design and tumor sites were observed. Porphyromonas gingivalis appears to increase the chance of both diseases, and it may be one of their main potential risk factors. Genetic predisposition is increased by exposure to environmental factors which can directly induce epigenetic changes that contribute to these diseases. Conclusions: Understanding the mechanisms related to periodontitis and HNC has increased, however, well-designed clinical studies are needed for better conclusions. Furthermore, the advent of multiple "omic" technologies will help comprehend their possible association.
\end{abstract}

Key words: Periodontitis, head and neck cancer, oral cancer, risk factors, biological factors.

\section{Introduction}

Head and neck cancer (HNC) is the seventh most common cancer in the world. There are about 890,000 new cases annually, with 450,000 deaths every year. The most common histological subtype is squamous cell carcinoma (SCC), and most cases occur in the oral cav- ity, sinonasal cavity, pharynx, and larynx. Risk factors include smoking, alcoholism, and human papillomavirus (HPV), with the latter being especially involved with the cases of oropharynx. Nevertheless, apart from those well-established risk factors, for oral cancer (OC), approximately $15 \%$ of them still cannot be explained, 
which led to the need to explore other potential risk factors $(1,2)$. Poor oral health, in particular, periodontitis has been hypothesized to be related to the development of HNC (3-15).

Periodontitis is a multifactorial inflammatory disease related with dysbiotic biofilm and characterized by progressive destruction of the tooth-supporting apparatus (16). It is estimated that severe periodontitis affects 538 million people worldwide, and it can lead to tooth loss which negatively impacts quality of life, making it a major public health problem (17). According to Van Dyke and Sheilesh (18), smoking and types 1 and 2 diabetes mellitus are well-established risk factors for periodontitis. In the last decades, several studies have identified alcohol and smoking as the major risk factors of $\mathrm{HNC}$, both associated with poor oral hygiene and, as such, are a possible link between periodontitis and cancer (19). Thus, it is important to understand the risk factors related to periodontitis and HNC and the possible association between the two diseases, in order to propose interventions for prevention therapy, risk reduction and changes in lifestyle (Fig. 1).

In the present study, we reviewed more than 20 years of published data concerning the possible relation between periodontitis and HNC. Highlights from these studies are discussed, including their limitations. The underlying biological mechanisms of periodontitis that could lead to HNC are also discussed aiming to better explore current findings.

\section{Material and Methods}

A search was conducted using the PubMed database addressing studies that analyzed the possible association between periodontitis and HNC or OC over 20 years (between January 1, 1999 and May 20, 2020) in order to understand the overall consensus in the literature concerning this subject. Keywords included: "tooth loss" or "gingival inflammation" or "alveolar bone loss" or "gingivitis" or "periodontitis" or "periodontal" and "tumor" or "carcinoma" or "oral cancer" or "cancer". Inclusion criteria were: (a) cohort, cross-sectional or case-control studies, (b) full-text articles, (c) and published in English. Case reports were excluded.

\section{Results}

In the total, 4,232 articles appeared in the search. Of these, 20 articles were selected based on the title and abstract. After reading the complete publications, 7 were excluded and 13 remained. For better analysis, we separated HNC from those that were exclusively of OC (Table 1).

\section{Discussion}

Overall, most studies reported a positive association between periodontitis and HNC or OC (4,5,7,8,10-15). Tezal et al. (14) focused on non-hispanic white men, while other authors $(4-13,15)$ included the entire population, mostly matching the controls with some clinical aspect, such as age, sex, and/or race to diminish bias.

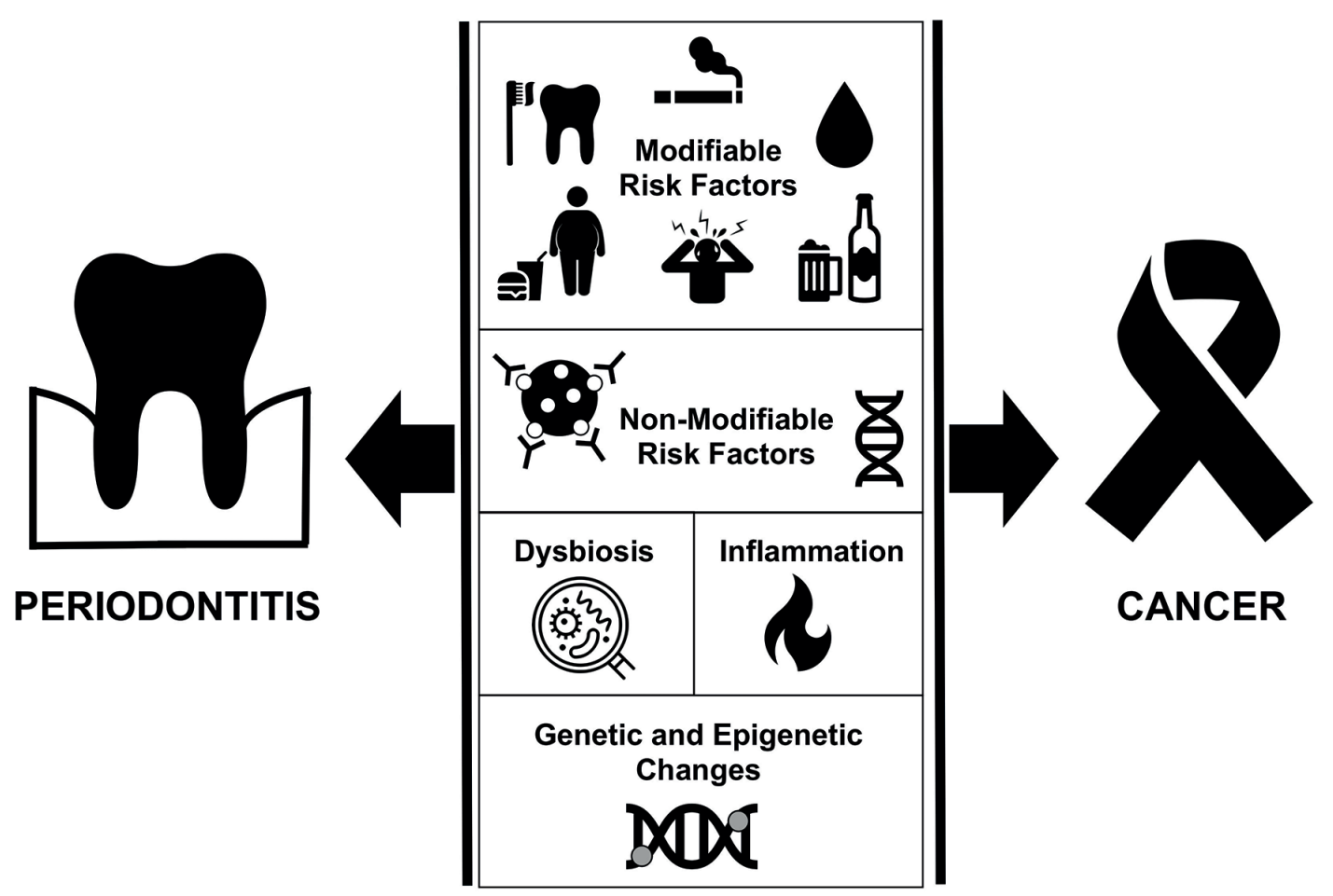

Fig. 1: Risk factors for periodontitis and cancer: Modifiable (smoking, diabetes mellitus, psychological factors, and lifestyle factors such as diet and alcoholism) and non-modifiable risk factors (host response and genetic factors). 
Table 1: Studies conducted between 1999-2020 that evaluated the association between periodontitis and head and neck or oral cancer.

\begin{tabular}{|c|c|c|c|c|c|c|c|c|}
\hline $\mathbf{n}$ & Authors & $\begin{array}{c}\text { Coun- } \\
\text { try }\end{array}$ & $\begin{array}{l}\text { Study de- } \\
\text { sign }\end{array}$ & Cases & Controls & $\begin{array}{c}\text { Periodontal } \\
\text { evaluation }\end{array}$ & $\begin{array}{c}\text { Odds ratio } \\
(95 \% \text { CI })\end{array}$ & Results \\
\hline \multicolumn{9}{|c|}{ HEAD AND NECK CANCER } \\
\hline 1 & $\begin{array}{l}\text { Saira et } \\
\text { al. (3) }\end{array}$ & $\begin{array}{l}\text { Paki- } \\
\text { stan }\end{array}$ & $\begin{array}{l}\text { Case-con- } \\
\text { trol }\end{array}$ & $\begin{array}{c}276 \text { oral, orophar- } \\
\text { ynx, pharynx, } \\
\text { hypopharynx, } \\
\text { larynx SCC }\end{array}$ & $\begin{array}{l}275, \text { age, eth- } \\
\text { nically and } \\
\text { linguistical- } \\
\text { ly-matched }\end{array}$ & $\begin{array}{l}\text { Not re- } \\
\text { ported }\end{array}$ & $\begin{array}{l}7.22(4.92- \\
10.59)\end{array}$ & $\begin{array}{l}\text { Periodontal diseases } \\
\text { were identified as a } \\
\text { significant predictor }\end{array}$ \\
\hline 2 & $\begin{array}{l}\text { Moraes et } \\
\text { al. (4) }\end{array}$ & Brazil & $\begin{array}{l}\text { Case-con- } \\
\text { trol }\end{array}$ & $\begin{array}{l}35 \text { oral and oro- } \\
\text { pharynx SCC }\end{array}$ & $\begin{array}{l}\text { 40, age and } \\
\text { sex-matched }\end{array}$ & $\begin{array}{l}\text { PPD, CAL, } \\
\text { BOP, PI and } \\
\text { GI }\end{array}$ & $\begin{array}{l}\text { Severity- } 10.9 \\
(1.9-61.2)\end{array}$ & $\begin{array}{c}\text { Chronic periodontitis } \\
\text { (extent and severity) } \\
\text { were risk factors for } \\
\text { cancer }\end{array}$ \\
\hline 3 & $\begin{array}{l}\text { Eliot et al. } \\
\text { (5) }\end{array}$ & USA & $\begin{array}{l}\text { Case-con- } \\
\text { trol }\end{array}$ & $\begin{array}{l}513 \text { oral, pharynx } \\
\text { and larynx SCC }\end{array}$ & $\begin{array}{l}\text { 567, age and } \\
\text { sex-matched }\end{array}$ & $\begin{array}{l}\text { Periodontal } \\
\text { disease } \\
\text { (self-report- } \\
\text { ed) }\end{array}$ & $\begin{array}{c}\text { Extent- } 12.5 \\
(2.3-67.6) \\
1.09(1.02-1.16)\end{array}$ & $\begin{array}{c}\text { Support an asso- } \\
\text { ciation between peri- } \\
\text { odontal disease and } \\
\text { HNSCC }\end{array}$ \\
\hline 4 & $\begin{array}{l}\text { Divaris et } \\
\text { al. (6) }\end{array}$ & USA & $\begin{array}{l}\text { Case-con- } \\
\text { trol }\end{array}$ & $\begin{array}{l}1289 \text { oral, phar- } \\
\text { ynx and larynx } \\
\text { SCC }\end{array}$ & $\begin{array}{l}\text { 1361, age, } \\
\text { sex and race- } \\
\text { matched }\end{array}$ & $\begin{array}{l}\text { Teeth lost } \\
\text { and mobil- } \\
\text { ity (self- } \\
\text { reported) }\end{array}$ & $\begin{array}{l}\text { Teeth lost- } 1.21 \\
(0.94-1.56)\end{array}$ & $\begin{array}{l}\text { No strong support for } \\
\text { any association be- } \\
\text { tween teeth loss and } \\
\text { HNSCC }\end{array}$ \\
\hline 5 & $\begin{array}{l}\text { Tezal et } \\
\text { al. (7) }\end{array}$ & USA & $\begin{array}{l}\text { Case-con- } \\
\text { trol }\end{array}$ & $\begin{array}{l}266 \text { oral, oro- } \\
\text { pharynx and } \\
\text { larynx SCC }\end{array}$ & $\begin{array}{l}207 \text { non- } \\
\text { matched } \\
\text { controls }\end{array}$ & ABL & $\begin{array}{l}\text { Teeth mobility- } \\
1.33(1.07-1.65) \\
4.36(3.16-6.01)\end{array}$ & $\begin{array}{l}\text { Chronic periodontitis } \\
\text { is an independent } \\
\text { risk factor for HN- } \\
\text { SCC and smoking } \\
\text { modifies this associa- } \\
\text { tion } \\
\end{array}$ \\
\hline 6 & $\begin{array}{l}\text { Rezende } \\
\text { et al. (8) }\end{array}$ & Brazil & $\begin{array}{l}\text { Case-con- } \\
\text { trol }\end{array}$ & $\begin{array}{l}50 \text { oral and oro- } \\
\text { pharynx SCC }\end{array}$ & $\begin{array}{l}\text { 50, age, sex } \\
\text { and social- } \\
\text { economic } \\
\text { status- } \\
\text { matched }\end{array}$ & CPITN & Not reported & $\begin{array}{c}\text { Cancer and more } \\
\text { severe periodontal } \\
\text { disease were associ- } \\
\text { ated }\end{array}$ \\
\hline \multirow[t]{4}{*}{7} & \multirow[t]{4}{*}{$\begin{array}{l}\text { Guha et } \\
\text { al. (9) }\end{array}$} & \multirow[t]{2}{*}{ Europe } & \multirow[t]{2}{*}{$\begin{array}{l}\text { Case-con- } \\
\text { trol }\end{array}$} & \multirow{2}{*}{$\begin{array}{c}924 \text { oral, oro- } \\
\text { pharynx, larynx } \\
\text { and esophagus } \\
\text { SCC }\end{array}$} & \multirow{2}{*}{$\begin{array}{l}928-\text { fre- } \\
\text { quently age } \\
\text { and sex- } \\
\text { matched }\end{array}$} & \multirow{2}{*}{\begin{tabular}{|l|} 
Oral hy- \\
giene and \\
missing \\
teeth (inter- \\
viewer)
\end{tabular}} & $\begin{array}{c}\text { Oral hygiene- } \\
2.89(1.74-4.81)\end{array}$ & \multirow{2}{*}{$\begin{array}{l}\text { Periodontal disease } \\
\text { may be independent } \\
\text { causes of cancers of } \\
\text { the head and neck }\end{array}$} \\
\hline & & & & & & & $\begin{array}{c}\text { Missing teeth } \\
0.70(0.44-1.11)\end{array}$ & \\
\hline & & \multirow{2}{*}{$\begin{array}{l}\text { Latin } \\
\text { Amer- } \\
\text { ica }\end{array}$} & \multirow[t]{2}{*}{$\begin{array}{l}\text { Case-con- } \\
\text { trol }\end{array}$} & \multirow{2}{*}{$\begin{array}{c}2286 \text { oral, oro- } \\
\text { pharynx, larynx } \\
\text { and esophagus } \\
\text { SCC }\end{array}$} & \multirow{2}{*}{$\begin{array}{l}\text { 1805- fre- } \\
\text { quently age } \\
\text { and sex- } \\
\text { matched }\end{array}$} & \multirow{2}{*}{$\begin{array}{l}\text { Oral hy- } \\
\text { giene and } \\
\text { missing } \\
\text { teeth (inter- } \\
\text { viewer) }\end{array}$} & $\begin{array}{c}\text { Oral hygiene- } \\
1.91(1.49-2.45)\end{array}$ & \multirow{2}{*}{$\begin{array}{l}\text { Periodontal disease } \\
\text { may be independent } \\
\text { causes of cancers of } \\
\text { the head and neck }\end{array}$} \\
\hline & & & & & & & $\begin{array}{l}\text { Missing teeth } \\
1.31(1.0-1.72)\end{array}$ & \\
\hline \multicolumn{9}{|c|}{ ORAL CANCER } \\
\hline 8 & $\begin{array}{l}\text { Shin et al. } \\
\text { (10) }\end{array}$ & Korea & $\begin{array}{l}\text { Case-con- } \\
\text { trol }\end{array}$ & 146 oral SCC & \begin{tabular}{|c|}
278 age, sex \\
and smok- \\
ing-matched
\end{tabular} & $\overline{\mathrm{ABL}}$ & $3.66(1.46-9.23)$ & $\begin{array}{c}\text { Periodontitis was } \\
\text { independently associ- } \\
\text { ated with oral SCC }\end{array}$ \\
\hline 9 & $\begin{array}{l}\text { Laprise et } \\
\text { al. (11) }\end{array}$ & India & $\begin{array}{l}\text { Case-con- } \\
\text { trol }\end{array}$ & 306 oral SCC & $\begin{array}{l}328 \text {, age and } \\
\text { sex-matched }\end{array}$ & $\begin{array}{c}\text { Gingival } \\
\text { inflamma- } \\
\text { tion and } \\
\text { recession }\end{array}$ & $1.83(1.10-3.04)$ & $\begin{array}{l}\text { Generalized gingival } \\
\text { recession was associ- } \\
\text { ated with oral SCCC }\end{array}$ \\
\hline 10 & $\begin{array}{l}\text { Narayan } \\
\text { et al. }(12)\end{array}$ & India & $\begin{array}{l}\text { Case-con- } \\
\text { trol }\end{array}$ & 242 oral SCC & $\begin{array}{l}\text { 254, age and } \\
\text { sex-matched }\end{array}$ & CPITN & Not reported & $\begin{array}{l}\text { Periodontal disease is } \\
\text { directly proportional } \\
\text { to oral SCC. }\end{array}$ \\
\hline 11 & $\begin{array}{l}\text { Moergel } \\
\text { et al. (13) }\end{array}$ & $\begin{array}{l}\text { Ger- } \\
\text { many }\end{array}$ & $\begin{array}{l}\text { Case-con- } \\
\text { trol }\end{array}$ & 178 oral SCC & $\begin{array}{l}\text { 123, sex- } \\
\text { matched }\end{array}$ & $\mathrm{ABL}$ & $2.4(1.5-3.80)$ & $\begin{array}{l}\text { Chronic periodontitis } \\
\text { and oral SCC were } \\
\text { associated }\end{array}$ \\
\hline 12 & $\begin{array}{l}\text { Tezal et } \\
\text { al. (14) }\end{array}$ & USA & $\begin{array}{c}\text { Case-con- } \\
\text { trol (non- } \\
\text { Hispanic } \\
\text { white men) } \\
\end{array}$ & 51 tongue $\mathrm{SCC}$ & $\begin{array}{l}54, \text { sex- } \\
\text { matched }\end{array}$ & $\mathrm{ABL}$ & $\begin{array}{c}5.23(2.64- \\
10.35)\end{array}$ & $\begin{array}{l}\text { Chronic periodontitis } \\
\text { and tongue cancer } \\
\text { risk in men were as- } \\
\text { sociated }\end{array}$ \\
\hline 13 & $\begin{array}{l}\text { Tezal et } \\
\text { al. (15) }\end{array}$ & USA & $\begin{array}{c}\text { Cross- } \\
\text { sectional } \\
(13,798 \\
\text { individuals })\end{array}$ & 131 oral tumor & $\begin{array}{c}\text { Non-matched } \\
\text { controls }\end{array}$ & $\mathrm{CAL}$ & $\begin{array}{l}4.57(2.25- \\
9.30)\end{array}$ & $\begin{array}{l}\text { Periodontal disease } \\
\text { and oral tumors risk } \\
\text { were associated }\end{array}$ \\
\hline
\end{tabular}

Abbrev.: $\mathrm{ABL}=\mathrm{Alveolar}$ bone loss; $\mathrm{BOP}=\mathrm{Bleeding}$ on probing; $\mathrm{CAL}=$ clinical attachment loss; $\mathrm{CI}=$ confidence interval; $\mathrm{CPITN}=\mathrm{Community}$ Periodontal Index of Treatment Needs; GI=Gingival index; HNSCC=head and neck squamous cell carcinoma; PI=Plaque index; PPD=Probing pocket depth; $\mathrm{SCC}=$ squamous cell carcinoma 
Shin et al. (10) observed that the relation between periodontitis and OC appears to increase in older (5 times more for patients over 60 years-old) and male patients (6.5 times more than in females), and Tezal et al. (14) noticed a 5.23 -fold increase in tongue cancer risk with each millimeter of alveolar bone loss (ABL). Furthermore, adjustment of confounding factors (for example, age, sex, education level, smoking, and alcohol drinking) showed that periodontitis is an independent risk factor $(10,11)$.

On the other hand, Divaris et al. (6) found no association between tooth loss (oral health assessment) and $\mathrm{HNC}$, showing that there is no consistency between all studies. Furthermore, although Guha et al. (9) reported that poor oral health seems to increase $\mathrm{HNC}$ risk in Europe, missing teeth in general were not associated with it. Additionally, in Latin America, missing 6 or more teeth seemed to enhance the risk of pharynx and larynx cancer, but no relation was observed with OC, showing variable results. It is important to notice that both Divaris et al. (6) and Guha et al. (9) used tooth loss as one of the criteria to evaluate periodontitis. This is not the ideal parameter since 30 to $40 \%$ of the cases of tooth loss in older subjects are due to cavities and their sequels rather than periodontitis (20).

Smoking and alcohol consumption are well-established risk factors for HNC (2). Thus, to evaluate if periodontitis is indeed a risk factor for HNC these variables were adjusted in most studies (4-7,9-11,14,15). Nevertheless, as both habits (smoking and drinking) are associated with the development of HNC and periodontitis, for future studies that analyze the relationship between periodontitis and $\mathrm{HNC}$ it should be interesting to include only patients with HNC who do not smoke or drink as this could lead to more concrete evidence.

A meta-analysis study have reported that periodontitis increases by 2.63 -fold the risk for HNC (21). Based on this, it has been speculated that the prevention and treatment of periodontitis could be important to decrease the incidence of $\mathrm{HNC}$ and improve its prognosis (7). Nevertheless, to confirm the overall findings well-conducted randomized controlled trials are still needed to be conducted. If this is indeed established, important oral health care policies should be promoted (22).

As for the evaluations used to define the presence of periodontitis, probing pocket depth (PPD) and clinical attachment loss (CAL) are considered the gold standard measurement to identify periodontitis. However, only 1 study used such parameters (4). Probably this occurred because PPD and CAL assessments are more complex methods than the others reported, taking up more time and requiring a proper room to be conducted, which probably made it not feasible. Most authors $(n=4)$ evaluated periodontitis by the presence of ABL using panoramic imaging. However, the quantity of bone loss that defined periodontitis was different between some studies $(7,10,13,14)$. Other periodontal assessments included missing teeth which, as already discussed, may not represent periodontitis, and visual examination or subject questionnaire may be associated with misleading results. Furthermore, studies based on the number of missing teeth may consider that, although unlikely, tooth loss may happen due to cancer and not as the cause of cancer. In addition, especially for the self-reported questionnaires, the educational status of the patient may influence the result as their perception of oral health may be different and result in deceptive conclusions (23). Apart from these different evaluations, one study did not describe the method used to define periodontitis (3) making it difficult to discuss its results as they may have overestimated the relation of periodontitis with OC. For the future, it is important that studies use a validated and optimal measurement of periodontitis, in order to decrease heterogeneity and increase accuracy.

Apart from the several periodontitis assessments that were used which made it harder to properly compare the studies, other limitations included: small sample size for some studies which can overestimate the results; population heterogeneity; differences in study design; varied HNC sites and adjustment of different confounding factors. When taking into consideration all these factors, the results must be interpreted with caution. If periodontitis is indeed a risk for $\mathrm{HNC}$, it is important to understand whether it has a direct or indirect relation with carcinogenesis.

Therefore, it is important to study the biological mechanisms underlying the possible role of periodontitis in HNC for deeper comprehension of the clinical findings. To better discuss these possible mechanisms, this part was divided into 3 topics: (i) microbiological mechanisms, (ii) common genetic factors (polymorphisms) and (iii) immunological mechanisms (epigenetic and inflammatory).

- Microbiological mechanisms

Recently, there was a change in understanding about the origin of microbial diseases. Periodontal diseases can now be explained by polymicrobial synergy and dysbiosis ("a state of imbalance in the relative abundance or influence of species within a microbial community associated with inflammatory disease") (24). Dental biofilm has long been recognized as the initiator of periodontal disease (16). Although the presence of pathogens is a predisposing factor, it is not enough to cause periodontitis. Currently, the most accepted hypothesis is that the oral microbiota dysbiosis interferes with host homeostasis, which leads to periodontitis (24). It is already known that of all microorganisms that colonize the mouth, three specific pathogens are identified as etiological agents in periodontitis: Porphyromonas gingivalis, Tannerella forsythia and Aggregatibacter 
actinomycetemcomitans (18). Among them, P. gingivalis is proposed as a keystone pathogen (25), causing in periodontitis dysbiosis and affecting the immune response. This bacterium has also been associated with other diseases, such as diabetes mellitus, cardiovascular diseases, preterm birth, rheumatoid arthritis, and pulmonary disease (26).

A systematic review and meta-analysis evaluated and compared the prevalence of $P$. gingivalis in cancer patients and showed that although there is no significant correlation between cancer and $P$. gingivalis (OR, 1.36; 95\% CI, 0.47-3.97), this bacterium may be associated with OC. This meta-analysis also highlighted that there were insufficient data associated with sex, smoking, age and alcohol, which are important variables that could potentially influence the malignancy process (27). Geng et al. (28) revealed the relationship between $P$. gingivalis, periodontitis, and cancer using bioinformatic analyses. In this study, it was demonstrated genetic alteration of $\mathrm{OC}$ and $\mathrm{HNC}$ in response to chronic infection with $P$. gingivalis.

A review of the possible role of periodontal pathogens in oral carcinogenesis has been published by Perera et al. (2) and showed that although recent studies have shown differences in microbial composition between healthy and carcinogenic tissues, they have not been able to agree with specific bacteria or oral microbial dysbiosis patterns implicated in SCC. In this way, there is evidence about the microbiological relationship between periodontitis and $\mathrm{HNC}$, but the mechanisms that are part of this process remain largely unknown.

- Common genetic factors (polymorphisms)

Genes constitute the transcriptionally active part of chromosomes, being structurally divided into introns (non-coding sequences) and exons (coding sequences). DNA sequences may have different variations, and the best known are single nucleotide changes, more commonly called by the abbreviation SNP (single nucleotide polymorphism) that can be found in all regions of a gene (29). A variety of genes may be associated with carcinogenesis. Human microsomal epoxide hydrolase and glutathione s-transferases genes are the most studied polymorphisms regarding the susceptibility to HNC in human. However, there is also an increased risk for $\mathrm{HNC}$ for p53 codon 72 Pro/Pro, variants of the ADH gene, and ALDH2 (30).

In 1997, Kornman et al. (31) investigated the association between polymorphism of the IL-1 gene and periodontitis severity and found that increased IL-1 production is a strong indicator of susceptibility to periodontitis (OR, 18.9; 95\%CI, 1.04-343.05, for ages 40-60 years). After these encouraging results, genetic studies on periodontitis began to focus on polymorphisms. Several polymorphisms were associated with periodontitis, including the Fc- $\gamma$ receptor, ILs-1,4,6,10,18, TNF- $\alpha$, vitamin D receptor, cluster of differentiation-14, MMP-1, Toll-like receptor-2 and 4, and COX-2. These studies suggested a connection between periodontitis and genetic variation, however, the relationship between polymorphisms and periodontitis is not always strong due to subtypes of periodontitis and population variations (24).

J. Xu et al. (32) evaluated the association between IL-1 $\beta$ polymorphism and cancer. This meta-analysis showed that both the $+3954 \mathrm{C} / \mathrm{T}$ and IL- $1 \beta-511 \mathrm{C} / \mathrm{T}$ polymorphisms might modulate cancer susceptibility. Both periodontitis and HNC are multifactorial diseases, and evidence shows that gene-environment interactions can modulate risk by being associated with multiple risk factors. Genetic predisposition or susceptibility to periodontitis and cancer can be substantially increased by exposure to environmental factors or decreased by control of environmental exposure (33). Thereby, future genetic studies using current strategies will be important to understand periodontitis and HNC.

- Immunological mechanisms (epigenetic and inflammatory)

Classical genetics cannot explain the variety of phenotypes within a population. In this context, epigenetics offers a partial explanation of these phenomena. In 1939, Waddington introduced the term to cite "the causal interactions between genes and their products, which bring the phenotype into existence." Today, epigenetic is related to changes in gene expression that are not coded in the DNA sequence, including chemical changes of DNA and associated proteins, which leads to chromatin remodeling and inactivation or activation of a gene (34). The best-known epigenetic marker is DNA methylation. In 1983, the correlation between cancer and DNA methylation was first demonstrated, where it was observed that the genomes of the cancer cells are hypomethylated in comparison to their normal counterparts (35). In the last decades, it has been observed that carcinogenesis occurs through a multi-stage process in which epigenetic changes in normal cells lead to the generation of highly malignant derivatives. According to Bais (36), smoking, alcohol, HPV, lifestyle changes, and environmental carcinogens could directly induce epigenetic changes and modifications in signaling pathways and enzymes to promote SCC growth and metastasis.

Inflammation is a primordial mechanism in health and disease. The main objective of the inflammatory response is to identify and eliminate factors that affect homeostasis. The inflammatory response consists of four parts: 1) inflammatory inducers; 2) detecting sensors; 3) downstream mediators, and 4) target tissues that are affected (37). This process begins the immune response, involving innate and adaptive immunity. In this part, it seems that an important role is played by the epigenetic regulation of gene expression patterns, which occurs both in the positive regulation of pro-in- 
flammatory cytokines and other signaling molecules to activate a complete immune cell response, as well as in the regulation of anti-inflammatory cytokines. Cytokine genes have been targeted in multiple epigenetic events, such as active histone modifications at regulatory elements and transcriptional activation by loss of DNA methylation (24).

In 1997, Page and Kornman developed the classic pathogenesis model of periodontal disease. While this classic paradigm is still relevant, advances in knowledge have required it to be modified to accommodate new discoveries in the fields of microbiology and immunology. Thus, in the contemporary model of the pathogenesis of periodontitis, there is the transition from health to gingivitis and, finally, to periodontitis (38). The mechanisms involved in this process are related to gene activation pathways and associated with transient changes in the DNA methylation status. Epigenetic changes appear to regulate inflammation-specific genes in periodontitis (24). Recently, some findings suggest that bacteria have the potential to cause alterations in cellular DNA methylation (39). Also, according to Loo et al. (40), periodontitis may be associated with DNA hypermethylation, which is related to cancer risk factors. These findings show that cancer and chronic inflammation may have a similar epigenetic pattern, suggesting that DNA methylation may be a link between them.

Epigenetic changes may contribute to cancer, autoimmune and inflammatory diseases, including periodontitis. Recent studies have progressed the understanding of immunological mechanisms, however the knowledge about epigenetic and inflammatory mechanisms to explain the associations between periodontitis and $\mathrm{HNC}$ is still limited.

\section{Conclusions}

While it is true that our understanding of the mechanisms related to periodontitis and $\mathrm{HNC}$ has increased considerably in recent decades, many challenges remain. More studies are needed to understand these mechanisms and it is expected that with the advent of multiple "omic" technologies (genomics, epigenomics, transcriptomics, proteomics, metabolomics, metagenomics) the understanding of possible association between periodontitis and cancer will be increased. Furthermore, well-designed case-control studies should be encouraged for better conclusions.

Therefore, patients should be encouraged to change their lifestyle and adopt healthy habits (healthy eating, regular physical exercise), eliminate risk factors that may predispose them to cancer (smoking and alcohol), practice good oral hygiene, and visit regularly health professionals. Thus, the health multidisciplinary team must act together to reduce or eliminate potential risks that may affect the oral and systemic overall health of patients.

\section{References}

1. Bray F, Ferlay J, Soerjomataram I, Siegel RL, Torre LA, Jemal A. Global cancer statistics 2018: GLOBOCAN estimates of incidence and mortality worldwide for 36 cancers in 185 countries. CA Cancer J Clin. 2018;68:394-424.

2. Perera M, Al-Hebshi NN, Speicher DJ, Perera I, Johnson NW. Emerging role of bacteria in oral carcinogenesis: a review with special reference to perio-pathogenic bacteria. J Oral Microbiol. 2016;8:32762.

3. Saira, Khan MF, Khattak MR, Ahmed R, Malik S. Epidemiological and clinical correlates of oral squamous cell carcinoma in patients from north-west Pakistan. J Pak Med Assoc. 2019;69:5.

4. Moraes RC de, Dias FL, Figueredo CM da S, Fischer RG. Association between Chronic Periodontitis and Oral/Oropharyngeal Cancer. Braz Dent J. 2013;27:261-6.

5. Eliot MN, Michaud DS, Langevin SM, McClean MD, Kelsey KT. Periodontal disease and mouthwash use are risk factors for head and neck squamous cell carcinoma. Cancer Causes Control. 2013;24:1315-22.

6. Divaris K, Olshan AF, Smith J, Bell ME, Weissler MC, Funkhouser WK, et al. Oral health and risk for head and neck squamous cell carcinoma: the Carolina Head and Neck Cancer Study. Cancer Causes Control CCC. 2010;21:567-75.

7. Tezal M, Sullivan MA, Hyland A, Marshall JR, Stoler D, Reid ME, et al. Chronic periodontitis and the incidence of head and neck squamous cell carcinoma. Cancer Epidemiol Biomarkers Prev. 2009;18:2406-12.

8. Rezende CP de, Ramos MB, Daguíla CH, Dedivitis RA, Rapoport A. Oral health changes in with oral and oropharyngeal cancer. Braz J Otorhinolaryngol. 2008;74:596-600.

9. Guha N, Boffetta P, Wünsch Filho V, Eluf Neto J, Shangina O, Zaridze D, et al. Oral health and risk of squamous cell carcinoma of the head and neck and esophagus: Results of two multicentric casecontrol studies. Am J Epidemiol. 2007;166:1159-73.

10. Shin YJ, Choung HW, Lee JH, Rhyu IC, Kim HD. Association of Periodontitis with Oral Cancer: A Case-Control Study. J Dent Res. 2019;98:526-33.

11. Laprise C, Shahul HP, Madathil SA, Thekkepurakkal AS, Castonguay G, Varghese I, et al. Periodontal diseases and risk of oral cancer in Southern India: Results from the HeNCe Life study. Int J Cancer. 2016;139:1512-9.

12. Narayan TV, Revanna GM, Hallikeri U, Kuriakose MA. Dental Caries and Periodontal Disease Status in Patients with Oral Squamous Cell Carcinoma: A Screening Study in Urban and Semiurban Population of Karnataka. J Maxillofac Oral Surg. 2014;13:435-43.

13. Moergel M, Kämmerer P, Kasaj A, Armouti E, Alshihri A, Weyer $\mathrm{V}$, et al. Chronic periodontitis and its possible association with oral squamous cell carcinoma - a retrospective case control study. Head Face Med. 2013;9:2-7.

14. Tezal M, Sullivan MA, Reid ME, Marshall JR, Hyland A, Loree $\mathrm{T}$, et al. Chronic periodontitis and the risk of tongue cancer. Arch Otolaryngol Head Neck Surg. 2007;133:450-4.

15. Tezal M, Grossi SG, Genco RJ. Is Periodontitis Associated With Oral Neoplasms? J Periodontol. 2005;76:406-10.

16. Papapanou PN, Sanz M, Buduneli N, Dietrich T, Feres M, Fine DH, et al. Periodontitis: Consensus report of workgroup 2 of the 2017 World Workshop on the Classification of Periodontal and Peri-Implant Diseases and Conditions. J Periodontol. 2018;89:S173-82.

17. Kassebaum NJ, Smith AGC, Bernabé E, Fleming TD, Reynolds AE, Vos T, et al. Global, Regional, and National Prevalence, Incidence, and Disability- Adjusted Life Years for Oral Conditions for 195 Countries, 1990-2015: A Systematic Analysis for the Global Burden of Diseases, Injuries, and Risk Factors. J Dent Res. 2017;96:380-7.

18. Van Dyke TE, Sheilesh D. Risk factors for periodontitis. J Int Acad Periodontol. 2005;7:3-7.

19. Meyer MS, Joshipura K, Giovannucci E, Michaud DS. A review of the relationship between tooth loss, periodontal disease, and cancer. Cancer Causes Control CCC. 2008;19:895-907. 
20. Trovik TA, Klock KS, Haugejorden O. Trends in reasons for tooth extractions in Norway from 1968 to 1998. Acta Odontol Scand. 2000;58:89-96.

21. Zeng X-T, Deng A-P, Li C, Xia L-Y, Niu Y-M, Leng W-D. Periodontal disease and risk of head and neck cancer: a meta-analysis of observational studies. PloS One. 2013;8:e79017.

22. Xu S, Zhang G, Xia C, Tan Y. Associations Between Poor Oral Health and Risk of Squamous Cell Carcinoma of the Head and Neck: A Meta-Analysis of Observational Studies. J Oral Maxillofac Surg. 2018;77:2128-42.

23. Buhlin K, Gustafsson A, Andersson K, Håkansson J, Klinge B. Validity and limitations of self-reported periodontal health. Community Dent Oral Epidemiol. 2002;30:431-7.

24. Lindroth AM, Park YJ. Epigenetic biomarkers: a step forward for understanding periodontitis. JPeriodontal Implant Sci. 2013;43:111-20. 25. Hajishengallis G, Darveau RP, Curtis MA. The keystone-pathogen hypothesis. Nat Rev Microbiol. 2012;10:717-25.

26. Olsen I, Yilmaz Ö. Possible role of Porphyromonas gingivalis in orodigestive cancers. J Oral Microbiol. 2019;11:1563410.

27. Sayehmiri F, Sayehmiri K, Asadollahi K, Soroush S, Bogdanovic $\mathrm{L}$, Jalilian FA, et al. The prevalence rate of Porphyromonas gingivalis and its association with cancer: A systematic review and metaanalysis. Int J Immunopathol Pharmacol. 2015;28:160-7.

28. Geng F, Wang Q, Li C, Liu J, Zhang D, Zhang S, et al. Identification of Potential Candidate Genes of Oral Cancer in Response to Chronic Infection With Porphyromonas gingivalis Using Bioinformatical Analyses. Front Oncol. 2019;9:91.

29. Corella D, Ordovas JM. Basic Concepts in Molecular Biology Related to Genetics and Epigenetics. Rev Espanola Cardiol Engl Ed. 2017;70:744-53.

30. Hiyama T, Yoshihara M, Tanaka S, Chayama K. Genetic polymorphisms and head and neck cancer risk (Review). Int J Oncol. 2008;32:945-73.

31. Kornman KS, Crane A, Wang HY, di Giovine FS, Newman MG, Pirk FW, et al. The interleukin-1 genotype as a severity factor in adult periodontal disease. J Clin Periodontol. 1997;24:72-7.
32. Xu J, Yin Z, Cao S, Gao W, Liu L, Yin Y, et al. Systematic review and meta-analysis on the association between IL-1B polymorphisms and cancer risk. PloS One. 2013;8:e63654.

33. Zhang J, Sun X, Xiao L, Xie C, Xuan D, Luo G. Gene polymorphisms and periodontitis. Periodontol 2000. 2011;56:102-24.

34. Larsson L, Castilho RM, Giannobile W V. Epigenetics and its role in periodontal diseases: a state-of-the-art review. J Periodontol. 2015;86:556-68.

35. Robertson KD. DNA methylation and human disease. Nat Rev Genet. 2005;6:597-610.

36. Bais M V. Impact of Epigenetic Regulation on Head and Neck Squamous Cell Carcinoma. J Dent Res. 2019;98:268-76.

37. Freire MO, Van Dyke TE. Natural resolution of inflammation. Periodontol 2000. 2013;63:149-64.

38. Murakami S, Mealey BL, Mariotti A, Chapple ILC. Dental plaqueinduced gingival conditions. J Clin Periodontol. 2018;45:S17-27. 39. Barros SP, Offenbacher S. Modifiable risk factors in periodontal disease: epigenetic regulation of gene expression in the inflammatory response. Periodontol 2000. 2014;64:95-110.

40. Loo WTY, Jin L, Cheung MNB, Wang M, Chow LWC. Epigenetic change in E-cadherin and COX-2 to predict chronic periodontitis. J Transl Med. 2010;8:110.

\section{Funding}

None declared.

\section{Conflict of interest}

None declared.

\section{Authors contributions}

LM Gasparoni did the conceptualization, data curation, investigation, and writing-original draft. FA Alves, M Holzhausen and CM Pannuti were responsible for the conceptualization, methodology, supervision, writing-review and editing, and MS Serpa participated in the conceptualization, data curation, investigation, methodology, writing-original draft, review and editing. 